\title{
JORDANIAN CULTURE AND TRADITIONS AS A DRIVING FORCE FOR ATTRACTING DUTCH TOURISTS
}

\author{
Bashar Shukri MAAIAH* \\ Yarmouk University, Faculty of Tourism and Hotel Management, Department of Tourism, Management, Irbid, Jordan, e-mail: Bashar.maaiah@ yu.edu.jo
}

Osama Naser WOUHOUSH

Yarmouk University, Faculty of Tourism and Hotel Management, Department of Tourism, Management, Irbid, Jordan, e-mail: osamanaser93@hotmail.com

Citation: Maaiah, B.S., \& Wouhoush, O.N. (2020). JORDANIAN CULTURE AND TRADITIONS AS A DRIVING FORCE FOR ATTRACTING DUTCH TOURISTS. GeoJournal of Tourism and Geosites, 33(4spl), 1450-1455. https://doi.org/10.30892/gtg.334spl01-592

\begin{abstract}
Cultural tourism is one of the fastest growing and attracting tourism types in Jordan especially for European tourists. This study aims to analyze the role of the Jordanian traditional aspects in motivating Dutch tourists to visit Jordan. It also shows the technological applications needed to ensure the efficient involvement of Jordanian traditions in the tourism industry. Semi-structured interviews with two groups of participants were performed. The results indicate that the Jordanian traditions are attractive to Dutch tourists once authenticity is provided, which fulfills their cultural needs, thus their satisfaction and Word Of Mouth are generated in their feedback.
\end{abstract}

Key words: Dutch tourists, Jordan, marketing, tourism, traditions.

$$
* \quad * \quad * \quad * \quad * \quad *
$$

\section{INTRODUCTION}

Tourism is considered as one of the fastest growing industries in the world which forms a crucial segment of the Gross Domestic Product (GDP) of modern economies. This growth generated developments in the service sector, infrastructures, and employment. Sustainability of growth in the tourism sector demands the existence of variable types of tourism that ensure the fulfilment of the tourists' needs and wants.

\section{Tourism in Jordan}

Jordan is characterized with the existence of variable tourist attractions (natural and cultural), this diversity enables activities which can meet the needs and wants of a wide scale of tourists. Natural attractions in the country vary from green mountains in the north, beautiful rock formations, deserts, all the way to the red sea in the south and the lowest point on earth and world's biggest spa, the Dead Sea (Zalloom, 2020). Jordan has a rich cultural heritage represented by historical monuments introducing many crucial civilizations that passed on the area, such as the Nabatean, Roman, Byzantine, and Islamic (Goussous and Al-Jaafreh, 2020).

Cultural tourism is one of the fastest growing types of tourism; cultural tourists are characterized by having special travel motivations, which can be folklore, heritage, archaeology, art, galleries and traditions (Richards, 2016). The diversity of cultural tourists' demands generates a necessity for enabling variable types of cultural activities or attractions to fulfil those needs. One of the most important cultural aspects in any country are the traditions of the indigenous people (Butler, 2007). Traditions are considered as one of the most important aspects of the culture, it forms an important part of people's life and it shows their lifestyle. In Jordan, traditions are still strongly noticed including the people's lifestyle (hospitality and daily social life), ceremonies and events (such as weddings), dress codes, and cuisine.

\section{Traditions \& tourism}

The term tradition means the combination of beliefs and behaviour of people which are passed from one generation to another; however there is no term that defines all traditions (Lewis and Hammer, 2007). According to the literature, traditions' segments appeared as (a) lifestyle, which include the way people live in villages or Bedouin areas (Oweis et al., 2012), (b) cuisine, including the traditional food and beverage and the ceremonies accompanying it (Kivela and Crotts, 2006), (c) traditional dress codes, including the embroidery arts and needlework for men and women(Al Haija, 2011), and (d) events and festivals, such as weddings (Abu-Khafajah, 2011).

According to Baltus (2018) the Dutch are considered as one of the most travelling populations around the world, with approximately $88 \%$ of the population travelling abroad for tourism purposes, i.e.13 million Dutch tourists a year. Aconsiderable number of Dutch tourists are linterested in discovering new cultures and are motivated to discover them. However, and according to the Jordanian Ministry of Tourism and Antiquities, Jordan has received only 14000 Dutch tourists in 2016, which indicates that only (0.00088\%) (MOTA, 2018), of them have visited Jordan, representing a very modest number that gives an indicator for the need for more publicity for Jordan in the Dutch tourism market. Several factors including: high numbers of outbound Dutch tourists, the interest of a decent number of them in cultures traditions and ecological tourism, the existence of Jordanian traditions, and the modesty of Dutch tourists numbers in Jordan create a need to find an efficient marketing plan that can attract Dutch tourists to visit Jordan through the involvement of the Jordanian traditions in the tourism marketing process. The involvement of Jordanian traditions enhances the authenticity of the trip and helps in the preservation of the Jordanian traditions, thus this involvement depends on a win-win strategy for tourists and the host community.

\section{LITERATURE REVIEW}

\section{Tourism in Jordan}

The Hashemite Kingdom of Jordan is an Arab country located in the heart of the middle-east in the western part of Asia with an area of $(89,213)$ square kilometres. According to the United Nations Report (2019), the country is populated by 9.5 million people, the majority of

\footnotetext{
${ }^{*}$ Corresponding author
} 
them are Muslims (96\%) and (4\%) are Christians. The country is characterized with high standards of safety and security which encourages many businesses to take place in it (Bader et al., 2016). Jordan has a decent destination brand image; being the leader in receiving medical tourists in the Middle East (Al-Azzam et al., 2016). Tourism in Jordan relies upon the country's natural and cultural resources (Fischer et al., 2009). Furthermore, the welcoming atmosphere of the Jordanian people for guests and their decent knowledge about tourism are considered as crucial attractions for tourists (Fischer et al., 2009; Alhasanat and Hyasat, 2011; Zamil, 2011).

The diversity of tourism attractions in Jordan helped in increasing the numbers of inbound tourists since the 90s, (Barham et al., 2007), This increase is caused by the existence of various types of tourism that can take place in the country, such as archaeological, religious (Christian and Islamic), adventurous, natural or cultural (Barham et al., 2007; Shunnaq et al., 2008; Neveu, 2010). Tourism is considered as an important source of economic growth in Jordan. It is a sector that needs more social and governmental focus and support in order to generate more benefits (Mahadin et al, 2020,) and more improvements in the service sector (Al-Makhadmah, 2020; Rousan et al., 2020; Khaleefah, 2020). Nevertheless, it causes some problems for the Jordanian destinations such as the commodification of heritage and the change in the local values (Porter and Salazar, 2005; Lanquar, 2015). Recently, the Jordanian government has started the process of rehabilitating some of the Jordanian traditions for its importance for tourism (Trillo et al., 2020).

\section{Traditions and tourism marketing}

Nations around the world are no longer depending on traditional manufacturing as the main element of economy (Kotler, 2002), but on new types of skills and services (Pidgrina, 2007), which are now forming the bulk of the economies. One of the most important activities for such an economic growth is tourism, which is known as one of the fastest growing sectors in the world, especially in third world countries (Echtner and Prasad, 2003). This needs successful marketing for cities and places (Kotler et al., 1993). Marketing was defined by the American Marketing Association as "the activity, set of institutions, and processes for creating, communicating, delivering, and exchanging offerings that have value for customers, clients, partners, and society at large" (Ringold and Weitz, 2007, pp253).

Tourism marketing is defined as, " a management philosophy which, in the light of tourist demand, makes it possible through research, forecasting and selection of tourism products/services from suppliers, on the line with organization's purpose and tourist satisfaction." (Sharma, 2013). Accordingly, the loyalty for tourism marketers can be reached by satisfying the tourists' expectations and wants (Al Muala and Al Qurneh, 2012). Nowadays, tourism marketers are using the new wave of technologies, such as the virtual tourist communities in tourism marketing (Wang et al., 2002). Furthermore, using the World Wide Web is considered to be crucial in marketing tourism destinations (Doolin et al., 2002). The success of the marketing strategy relies on fulfilling each tourist's wants, and treats him as a unique individual in all relevant sectors (travel, accommodation, food and beverage, and recreation and entertainment (Jönsson, 2005).

Tourism marketers are searching for new alternative methods to increase the attractiveness of destinations and motivate tourists to favour it depending on several factors: accessibility, amenities, and local community (Rehman et al., 2020; Reitsamer et al., 2016). The sustainable tourism marketing process sets the involvement of local people and their traditions a priority, and cares about keeping the issue of its preservation away from commodification, which can be noticed in mass tourism (Jovicic, 2016). The involvement of indigenous people in local areas increases destination attractiveness through the traditional hospitality, which makes tourists feel welcomed and treated with generosity (Karayilan and Cetin, 2016). Additionally, marketing for tourism destinations by the involvement of indigenous people, is crucial for tourism marketing and the tourism process in general. Tourism presents a mechanism to promote, preserve and save traditions, as much as traditions help to increase the tourism destination attractiveness and competitiveness (Pickett et al., 2018).

The existence of traditions of one place gives it a unique destination brand and name, thus higher level of competitiveness and attractiveness in the process of tourism marketing (Singh et al., 2016). In tourism, marketing is known as an exchange that generates satisfaction for both the host (the city or the destination) and the guest (the visitor). Successful tourism marketing is the process that convinces the tourist to visit the destination and creates an intention to repeat the visit (Kolb, 2006). In tourism marketing, the marketing process mixes (the $5 \mathrm{Ps}$ ) which are the price, promotion, product, place and people, and applies them on the tourism sector segments depending on modern methods, such as the electronic Word Of Mouth (e-WOM) (Wolfe and Crotts, 2011) which has a crucial effect on the choice of potential tourists (positively or negatively) (Magatef, 2015). One of the most important elements in the process of tourism marketing is the attractiveness of the destinations and its ability to have a more solid push and pull factors (Pesonen et al., 2011).

\section{WOM and e-WOM}

The e-WOM is a dynamic information provider for tourists, which affects their choice of purchase (Litvin et al., 2008). The WOM and the e-WOM are becoming more affective, in comparison with the traditional methods used to obtain information, since they are cheaper, faster and more accessible for potential tourists all over the world (Trusov et al., 2009). Tourists sharing their past experiences upon returning home is a vital part of tourism marketing (Prebensen et al., 2010). When the actual experience meets the expectations of tourists, their level of satisfaction will increase and this will generate a positive feedback and WOM. This in turn will reach potential tourists and increase their interest in visiting the destination (Phillips et al., 2013). WOM is affected by important factors, such as the satisfaction of tourists during their visit (Simpson and Siguaw, 2008). WOM is very important because it can affect the choice of travelling of new tourists, it also helps stakeholders to realize the changes and the developments needed in the tourism destination (Hanlan and Kelly, 2005).

Nowadays, sharing feedback on the internet such as online reviews of travellers is increasing, and it is forming a vital reason to use the World Wide Web. Many tourists rely on it in order to reduce the risk that may be taken in choosing a destination (López and Farzan, 2014; Filieri and McLeay, 2014).

\section{Dutch tourists}

The Netherlands is located in north-western Europe, with a population of 17 million people, and a very flat geographical nature (Schaufeli, 2018), famous for its cycling roads, the practicality of its people and their enjoyment of life (Pojani et al., 2017). Since 1993, the Netherlands is considered as one of the most important countries in outbound tourism in addition to being one of the highest outbound tourists' exporters in the world with approximately 36 million trips taken annually by Dutch tourist (Bronner and de Hoog, 2011; Isaac, 2008; Kozak et al., 2008). Dutch tourists are characterized by being the fifth highest- spending tourists while seeking high quality services and activities during their trips, with 54\% of their expenditures being on transportation and $46 \%$ is divided among accommodation, transportation, and personal expenses (Anyango et al., 2013; Thrane and Farstad, 2012; Perez and Juaneda, 2000).

Dutch outbound tourists have recorded their highest numbers in history in the year 2018 , where $82 \%$ of the population have tra velled outside the Netherlands for tourist activities (13 million Dutch tourists), which is considered as the largest growth rate by $18 \%$ in 
comparison with the year 2016. The Netherlands is expected to export approximately 40 million tourists by the year 2020 (UNWTO, 2002). This indicates that Dutch tourists are characterized by having up to three tourism trips annually per person. This generates a need to increase Jordan's market share of the Dutch outbound tourism market.

Dutch tourists' interest in culture is obvious and they are having a decent amount of travel motivations (Romão et al., 2015). Dutch tourists are concerned with traditional cultural aspects of the tourism activity; this was obvious in many events that have witnessed their high attendance when the sharing of cultures and traditions existed (Richards and Wilson, 2004).

To achieve the aim of the study, there must be deep understanding of Dutch tourists' interest in traditions, needs and wants tourists seek to fulfil, and the efficient methods to rely on to achieve a decent involvement of the Jordanian traditions in the tourism marketing process, from Dutch tourism experts and Dutch tourists' perspectives. Accordingly, qualitative methods were employed by conducting semistructured interviews, in the period between $18^{\text {th }}-\mathrm{Feb}-2019-14^{\text {th }}-\mathrm{Apr}-2019$, with Dutch tour operators and travel agencies managers and employees, in addition to interviewing Dutch tourists who visited Jordan in the period between $19^{\text {th }}-$ Feb $-2019-2^{\text {nd }}-$ Apr -2019 . The qualitative semi-structured interviews are a method of gaining further understanding of the research question (Miles and Gilbert, 2005). It enables the researcher to get in depth information through an open dialogue and discussion with interviewees, and it helps in surpassing the barriers, which helps the participant in expressing his/her opinions freely.

\section{MATERIAL AND METHODS}

\section{Population and Sampling}

The population of this study consists of managers and employees from Dutch tour operators and travel agencies located in the Netherlands who sell tours to Jordan, in addition to Dutch tourists who visited Jordan. Sampling depended on saturation point, which is a point achieved when no more information or codes are provided for the researcher and the answers of the interviews are being repeated (Urquhart, 2012). In order to reach the saturation points, the researcher conducted interviews with (22) Dutch tour operators and travel agencies managers and employees of the department responsible for selling tours to Jordan, in addition to (54) Dutch tourists who visited Jordan for tourism purposes. The number of the interviews was pertinent to the saturation point. For interviewing the Dutch tour operators and travel agencies, the researcher used a list containing names and contacts of Dutch tour operators located in the Netherlands and sell tours to Jordan. The researcher then reserved dates for the interviews for each interviewee. Furthermore, the researcher contacted Dutch tourists who visited Jordan to reserve an appointment with them for the interviews conducted via mobile phone.

\section{Pre-testing of the interviews (pilot study)}

In order to ensure that the interview questions are pertinent to the study aim and objectives, the researcher conducted a pilot study interviews with 7 Dutch tour operators and 20 Dutch tourists. The pilot study aimed to realize the questions recommended by participants, and highlight questions that were not clear. After the pilot study was conducted, more questions were added and a group of questions were removed to minimize repetition andto ensure that the information gained is pertinent to the study problem and topic. This will give a clear realization of the role of Jordanian traditions as a marketing tool in attracting Dutch tourists, and the inclusion of the gathered data in the interviews.

\section{Dutch tour operators and travel agencies interviews}

The first part of the interviews was conducted through mobile phone with Dutch tour operators and experts and aimed to gain in depth information about the importance of traditions in the tourism marketing process. It also aimed to evaluate its current situation in the tourism cycle from experts' perspectives, and the technologies they recommend for developing the tourism industry and the facilitation of experiencing traditions. This part of the contacted interviews provided information about the WOM and e-WOM importance as a new tourism marketing channel.

\section{Dutch tourists' interviews}

Dutch tour operators and travel agencies' interviews were conducted in the period (18 ${ }^{\text {th }}$-February- 2019 to 4 -April-2019) and lasted between 26 to 35 minutes, while the Dutch tourists' interviews were conducted in the period of $\left(18^{\text {th }}\right.$-February- 2019 to $4^{\text {th }}$-April-2019) and its' duration varied between 18 - 45 minutes. Snowball sampling appeared for the researcher during the interviews through being provided with contacts of Dutch tourists who visited Jordan and were interested in participating in the interviews.

Interviewing Dutch tourists who visited Jordan aimed to build a solid knowledge about the level of interest they have towards Jordanian traditions, and to what extent it enhances their experience during their visit. Questions aimed to measure their enthusiasm for traditions and the needs they seek to fulfil by experiencing them, and to realize the needed technological applications that facilitate experiencing the Jordanian traditions in the periods of pre, during and post visit. Interviews with Dutch tourists' started with introductory questions, then continued to be more specific towards the role of Jordanian traditions in attracting them to visit the country and how it can provide a positive WOM which can be shared with potential tourists and affect their choice of destinations purchase.

\section{Data analysis}

Analysis of the interviews was conducted using the Nvivo 12 software, together with thematic analysis, in addition to the manual analysing of the interviews which enabled the researcher to analyse the gathered data and transform them into results.

In order to achieve the aim of the study, data analysis depended on gaining the most critical information provided by participants, and transformed it into clear findings which measures the Jordanian traditions attractiveness to Dutch tourists, the Jordanian traditions role in the tourism marketing process, the most decent technologies to rely on, and the importance of (WOM) and the (e-WOM)

\section{RESULTS AND DISCUSSION}

\section{Jordanian traditions and the tourism marketing of Jordan}

Participants in the interviews agreed that Jordanian traditions' role in the tourism marketing process is fundamental. This importance springs from an important theme and a crucial element it supports that is 'authenticity'. Experiencing Jordanian traditions during the tour enhances it through enabling the encounter of originality with local indigenous people who do not work in the tourism industry. In other words, tourists will feel more relaxed and welcomed when they are with people living in villages or Bedouin areas with no commercial backgrounds. Enhancing the authenticity of the trip leads to satisfying and fulfilling the cultural needs of tourists, and thus increasing their level of satisfaction which will then generate a positive feedback that will reach a wide scale of potential tourists (Figure 1).

In the marketing process for potential tourists, experts believe that marketing campaigns are ought to include materials which show the 
way indigenous people live. This will be more attractive for tourists seeking a new cultural experience. However, experts indicated that Jordanian traditional aspects are not gaining the amount of attention in the marketing campaigns and most of the focus is on the tourism highlighted destinations i.e. the most famous places. Accordingly, it is suggested to increase the participation of the Jordanian traditional aspects in the marketing campaigns of Jordanian tourist destinations.

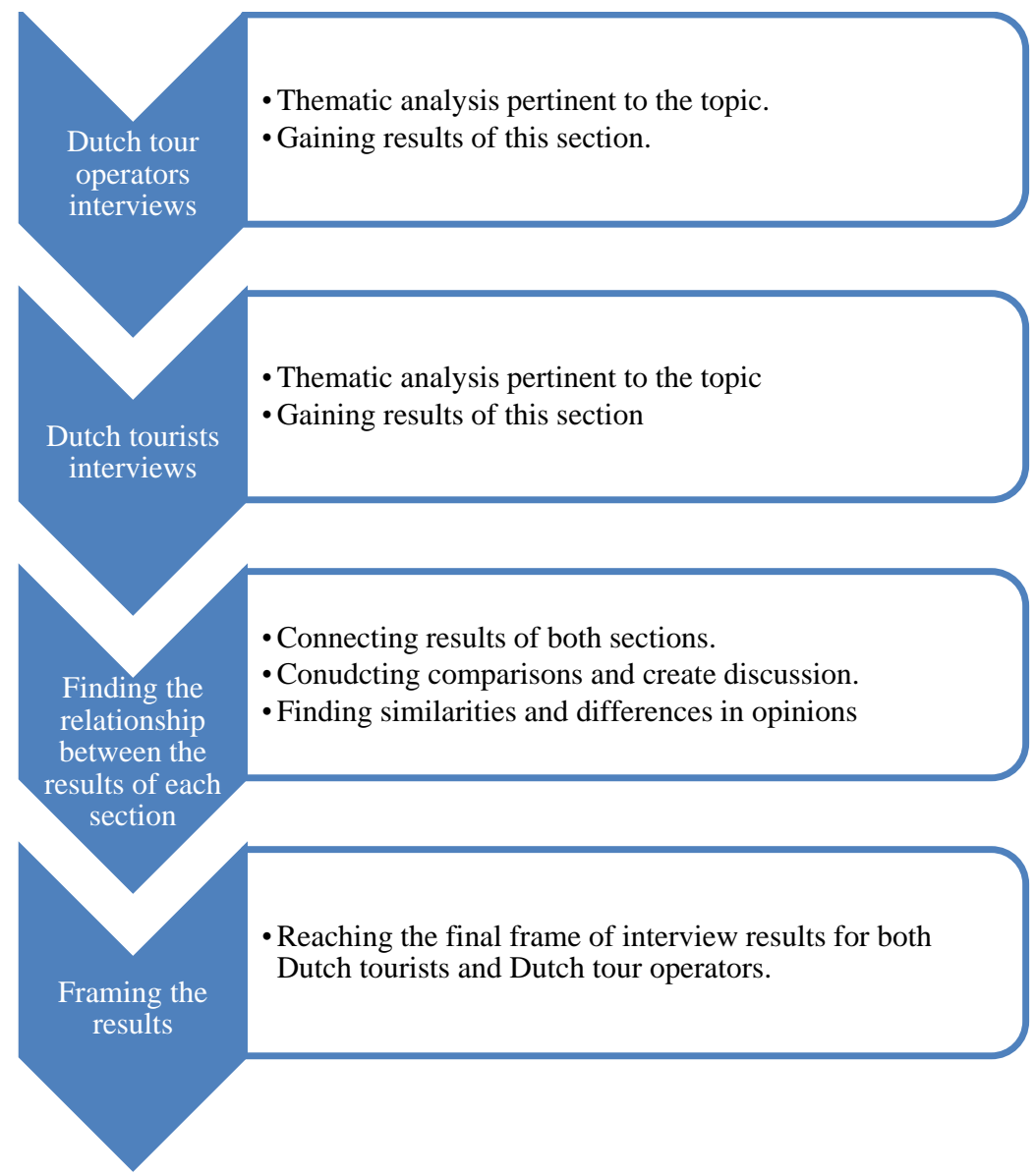

Figure 1. Data Analysis Process

\section{Jordanian traditions and Dutch tourists}

The study indicates that Jordanian traditions involvement is demanded by Dutch tourists for its' role in enhancing the authenticity and as a participant in the interviews called it 'the real soul of the country"' which fosters their satisfaction and generates a positive WOM that will be delivered to a decent number of potential tourists.

The study found a ranking for the most attractive Jordanian traditions for Dutch tourists as follows: the most attractive tradition was the Jordanian traditional lifestyle, which includes the daily life of Jordanian people and the way they welcome guests. However, it was the least experienced tradition because of the itineraries time limit and its' design which only focuses on the famous tourists destinations and ignores the traditional aspects. The second most attractive aspect found is the Jordanian traditional cuisine, including the dishes and the ceremonies accompanying it, such as weddings and festivals. Lastly, the thirdmost attractive tradition is the Jordanian traditional clothing.
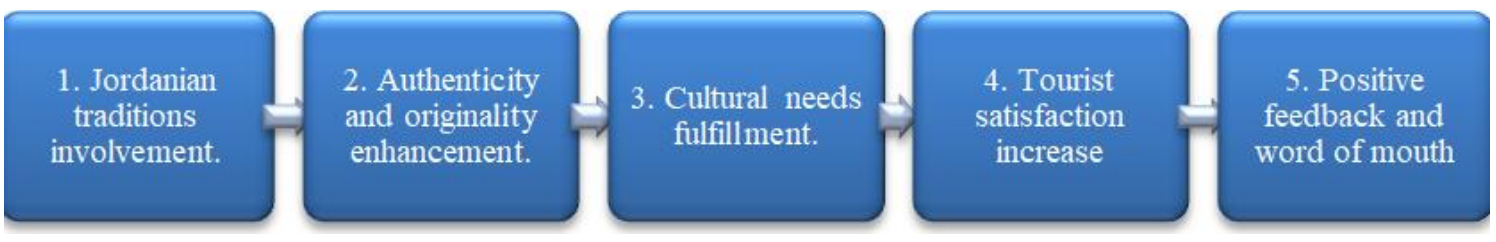

Figure 2. Jordanian Traditions Role in Tourism Marketing

\section{Jordanian traditions and technology}

The study revealed the most reliable technological applications to depend on in the process of increasing the involvement of Jordanian traditions from Dutch tourists' perspective. The dependence on those technologies is divided into three sections, and each section depends on a specific time period which is pre, during and post visit. Table 1 explains the needed technologies for facilitating the experience of Jordanian traditions for Dutch tourists.

\section{WOM and e-WOM as a marketing channel}

The study indicated that Dutch tourists consider WOM and e-WOM as their first source of trusted information; because it is from regular tourists who have no advertising or commercial backgrounds. Results show that most Dutch tourists share their opinions about the touristic experience they had in destinations they visited. According to the interviews, participants who encountered the traditional aspects gave it a decent percentage of their feedback shared to their friends and relatives. Technological developments facilitated the process of delivering 
their ideas and opinions to people around the world using many applications and websites available, such as Google review, Trip advisor etc., or by sharing pictures and videos on social media. Such reviews affect the choice of purchase of potential tourists.

Table 1. Technologies for facilitating the experience of Jordanian traditions for Dutch tourists

\begin{tabular}{|c|c|}
\hline Time period & Technological applications relied on \\
\hline Pre-visit & $\begin{array}{ll}- & \text { Online reviews, such as Google reviews, Trip advisor. } \\
\text { - } & \text { Social media posts, such as Instagram and Facebook } \\
\text { - } & \text { Websites and web-pages including information about the destinations. }\end{array}$ \\
\hline During visit & $\begin{array}{ll}- & \text { Navigation applications. } \\
\text { - } & \text { Translation applications. } \\
\text { - } & \text { E-guides (software explaining about tourist places; were to go and what to do }\end{array}$ \\
\hline Post visit (Feedback) & $\begin{array}{ll}\text { - } & \text { Social media, such as Facebook and Instagram } \\
\text { - } & \text { Online review applications, such as Google review and Trip advisor }\end{array}$ \\
\hline
\end{tabular}

\section{CONCLUSION}

In summary, the current study, revealed the importance of Jordanian traditions in attracting Dutch tourists and enhance their touristic experience, which was highlighted by their preference for several aspects of Jordanian traditions, such as cuisine, ceremonies and clothing which was considered to be the most attractive touristic aspect.

Experiencing Jordanian traditions raised the levels of Dutch tourists' satisfaction, and thus generated a positive feedback about the tour in general. This can motivate potential tourists looking for a destination to travel for their holidays or any other tourism purposes. Accordingly, the role of WOM and e-WOM is important, and its' importance is growing because of the technological developments enabling knowledge about different experiences to be shared with a wide scale of people.

\section{REFERENCES}

Abu-Khafajah, S. (2011). Meaning-making process of cultural heritage in Jordan: The local communities, the contexts, and the archaeological sites in the Citadel of Amman. New Perspectives in Global Public Archaeology, 183-196. Springer, New York, NY. https:doi.org/10.1007/978-1-4614-0341-8_14

Al-Azzam, A. (2016). A study of the impact of marketing mix for attracting medical tourism in Jordan. International Journal of Marketing Studies, 8(1), 139149. https:doi.org/10.5539/ijms.v8n1p139

Al Haija, A.A. (2011). Jordan: Tourism and conflict with local communities. Habitat International, 35(1), 93-100, https:doi.org/10.1016/j.habitatint.2010.04.002.

Alhasanat, S., \& Hyasat, A. (2011). Socio cultural Impacts of Tourism on the Local Community in Petra Jordan. Jordan Journal of Social Sciences, 166(742), 1-30. https:doi.org/10.1080/04353684.1982.11879467

Al-Makhadmah, I.M. (2020).The role of virtual museum in promoting religious tourism in Jordan. GeoJournal of Tourism \& Geosites, 28(1), 268-274. https:doi.org/10.30892/gtg.28121-468

Al Muala, A., \& Al Qurneh, M. (2012). Assessing the relationship between marketing mix and loyalty through tourists satisfaction in Jordan curative tourism. American Academic \& Scholarly Research Journal, 4(2), 1, Corpus ID: 130904733.

Anyango, N.M., Duim, R., \& Peters, K. (2013). Spending of Dutch tourists: the locality of money. Annals of Tourism Research,43, 639-642. https:doi.org/10.1016/j.annals.2013.07.004

Bader, M., Alrousan, R., Abuamoud, I., \& Alasal, H.A. (2016). Urban Tourism in Jordan: Challenges and Opportunities Case Study: Amman. British Journal of Economics, 1-11. https:doi.org/10.9734/BJEMT/2016/24589

Baltus. (2018). Outbound tourism The Netherlands highest figures in history. https://www.baltuscommunications.com/en/news/outbound-tourism-thenetherlands-highest-figures-in-history

Barham, N., Dorry, S., \& Schamp, E.W. (2007). Relational Governance and Regional Upgrading in Global Value Chains-The Case of Package Tourism in Jordan. Erde-Berlin, 138(2), 169-186.

Bronner, F., \& de Hoog, R. (2011). Economizing behaviour during travel: Strategies and information sources used. Journal of Vacation Marketing, 17(3), 185195. https:doi.org/10.1177/1356766711409180

Butler, R. (2007). Tourism and indigenous peoples: Issues and implications. Routledge. https:doi.org/10.1080/14724040902786641

Doolin, B., Burgess, L., \& Cooper, J. (2002). Evaluating the use of the Web for tourism marketing: a case study from New Zealand. Tourism management, 23(5), 557-561. https:doi.org/10.1016/S0261-5177(02)00014-6

Echtner, C.M., \& Prasad, P. (2003). The context of third world tourism marketing. Annals of Tourism research, 30(3), 660-682. https:doi.org/10.1016/S01607383(03)00045-8

Filieri, R., \& McLeay, F. (2014). E-WOM and accommodation: An analysis of the factors that influence travelers' adoption of information from online reviews. Journal of Travel Research, 53(1), 44-57. https://doi.org/10.1177/0047287513481274

Fischer, J., Khan, I., Khemani, T., Mak, D., \& Najmi, R. (2009). Jordan tourism cluster. Report For Microeconomics of Competitiveness, 8.

Goussous, J., \& Al-Jaafreh, O. (2020). Sustainable Tourism Development in Historical Cities Case Study: Karak, Jordan. In Sustainable Development and Social Responsibility, 2, 319-332, Springer, Cham. https:doi.org/10.1007/978-3-030-32902-0_34

Hanlan, J., \& Kelly, S. (2005). Image formation, information sources and an iconic Australian tourist destination. Journal of Vacation Marketing, 11(2), 163177. https:doi.org/10.1177/1356766705052573

Isaac, R. (2008). Understanding the behaviour of cultural tourists: towards a classification of dutch cultural tourists. Academy of tourism, Science Guide. ISBN: 9789051798302.

Jönsson, C., (2005). Tourism Marketing Basics. University of the West Indies, 417-443. https:doi.org/10.1080/10548400802508499

Jovicic, D. (2016). Cultural tourism in the context of relations between mass and alternative tourism. Current Issues in Tourism, 19(6), 605-612. https:doi.org/10.1080/13683500.2014.932759

Karayilan, E., \& Cetin, G. (2016). Tourism destination: Design of experiences. In The handbook of managing and marketing tourism experiences, 65-83. Emerald Group Publishing Limited. https:doi.org/10.1108/978-1-78635-290-320161004

Khaleefah, Q. (2020). Is there a difference between the capabilities of foreign and domestic managers? A case study at five and four stars hotels in AqabaJordan. GeoJournal of Tourism and Geosites, 30(2spl), 861-867. https:doi.org/10.30892/gtg.302sp111-515

Kivela, J., \& Crotts, J.C. (2006). Tourism and gastronomy: Gastronomy's influence on how tourists experience a destination. Journal of Hospitality \& Tourism Research, 30(3), 354-377. https:doi.org/10.1177/1096348006286797

Kolb, B. (2006). Tourism marketing for cities and towns. Rutledge. https:doi.org/10.4324/9780080460758

Kotler, P., Haider, D.H., \& Rein, I. (2002). Marketing places: attracting investment, industry, and tourism to cities, states, and regions. Simon and Schuster. https:doi.org/10.1177/004728759403200383

Kotler, P., Haider, D.H., \& Rein, I. (1993). Marketing places: attracting investment, industry, and tourism to cities, states, and nations. The Free Press. https:doi.org/10.1080/10941660208722111

Kozak, M., Gokovali, U., \& Bahar, O. (2008). Estimating the determinants of tourist spending: a comparison of four models. Tourism Analysis, 13(2), 1, 43155. https://doi.org/10.3727/108354208785664283

Lanquar, R. (2015). Tourism in the Mediterranean. In Economic and social development of the southern and eastern mediterranean countries, 111-126, 
Springer, Cham. https:doi.org/10.1007/978-3-319-11122-3_8

Lewis, J.R., \& Hammer, O. (2007). The invention of sacred tradition. Cambridge University Press. https:doi.org/10.1017/CBO9780511488450

Litvin, S.W., Goldsmith, R.E., \& Pan, B. (2008). Electronic word-of-mouth in hospitality and tourism management. Tourism management, 29(3), 458-468. https:doi.org/10.1016/j.tourman.2007.05.011

López, C., \& Farzan, R. (2014).Analysis of local online review systems as digital word-of-mouth. In Proceedings of the 23rd International Conference on World Wide Web, 457-462, ACM. https:doi.org/10.1145/2567948.2576933

Magatef, S.G. (2015). The impact of tourism marketing mix elements on the satisfaction of inbound tourists to Jordan. International Journal of Business and Social Science, 6(7), 41-58.

Mahadin, B., Akroush, M.N., \& Bata, H. (2020). The effects of tourism websites' attributes on e-satisfaction and e-loyalty: a case of American travellers' to Jordan. International Journal of Web Based Communities, 16(1), 4-33. https:doi.org/10.1504/IJWBC.2020.105124

Miles, J., \& Gilbert, P. (Eds.).(2005). A handbook of research methods for clinical and health psychology. Oxford University Press on Demand. https://doi.org/10.1093/med:psych/9780198527565.001

Neveu, N. (2010). Islamic tourism as an ideological construction: A Jordan study case. Journal of Tourism and Cultural Change, 8(4), 327-337 https:doi.org/10.1080/4766825.2010.521252

Oweis, A., Gharaibeh, M., Maaitah, R., Gharaibeh, H., \& Obeisat, S. (2012). Parenting from a Jordanian perspective: findings from a qualitative study. Journal of Nursing Scholarship, 44(3), 242-248. https://doi.org/10.1111/j.1547-5069.2012.01455

Perez, E.A., \& Juaneda, S.C. (2000). Tourist expenditure for mass tourism markets. Annals of tourism research, 27(3), 624-637. https:doi.org/10.1016/S01607383(99)00101-2

Pesonen, J., Komppula, R., Kronenberg, C., \& Peters, M. (2011). Understanding the relationship between push and pull motivations in rural tourism. Tourism Review, 66(3), 32-49. https:doi.org/10.1108/16605371111175311

Phillips, W.J., Wolfe, K., Hodur, N., \& Leistritz, F.L. (2013). Tourist word of mouth and revisit intentions to rural tourism destinations: A case of North Dakota, USA. International journal of tourism research, 15(1), 93-104. https:doi.org/10.1002/jtr.879

Pickett, J.P., Scanlon, M., Peterson, R.D., \& O'Neil, S.T. (2018). Promoting Culture and Traditions of CumbeThrough Tourism.

Pidgrina, V., \& Filipchuk, N. (2020). Development of the tourist services market in Ukraine under conditions of transformation changes. GeoJournal of Tourism \& Geosites, 30(2spl), 794-800. https://doi.org/10.30892/gtg.302sp103-507

Pojani, D., Bakija, D., Shkreli, E., Corcoran, J., \& Mateo-Babiano, I. (2017). Do Northwestern and Southeastern Europe share a common "cycling mindset"? Comparative analysis of beliefs toward cycling in the Netherlands and the Balkans. European journal of transport and infrastructure research, 17(1). https:doi.org/10.18757/ejtir.2017.17.1.3178

Porter, B.W., \& Salazar, N.B. (2005). Heritage tourism, conflict, and the public interest: An introduction. International journal of heritage studies, 11(5), 361370. https:doi.org/10.1080/13527250500337397

Prebensen, N., Skallerud, K., \& Chen, J.S. (2010). Tourist motivation with sun and sand destinations: satisfaction and the wom-effect. Journal of Travel \& Tourism Marketing, 27(8), 858-873. https:doi.org/10.1080/10548408.2010.527253

Rehman, O.U., Liu, X., Rauf, A., Slama, M.B., \& Amin, W. (2020). Internet tradition and tourism development: A causality analysis on BRI listed economies. Tourism Economics, 26(6), 926-957. https:doi.org/10.1177/1354816619846251

Reitsamer, B.F., Brunner-Sperdin, A., \& Stokburger-Sauer, N.E. (2016). Destination attractiveness and destination attachment: The mediating role of tourists' attitude. Tourism Management Perspectives, 19, 93-101. https:doi.org/10.1016/j.tmp.2016.05.003

Richards, G. (2016). Cultural tourism. In Archaeological Displays and the Public, 1-11. Routledge, 2016. https:doi.org/10.1016/j.jhtm.2018.03.005

Richards, G., \& Wilson, J. (2004). The impact of cultural events on city image: Rotterdam, cultural capital of Europe 2001. Urban studies, 41(10), 1931-1951. https:doi.org/10.1080/0042098042000256323

Ringold, D.J., \& Weitz, B. (2007). The American Marketing Association definition of marketing: Moving from lagging to leading indicator. Journal of Public Policy \& Marketing, 26(2), 251-260. https:doi.org/10.1509/jppm.26.2.251

Romão, J., Neuts, B., Nijkamp, P., \& van Leeuwen, E. (2015). Culture, product differentiation and market segmentation: a structural analysis of the motivation and satisfaction of tourists in Amsterdam. Tourism Economics, 21(3), 455-474. https:doi.org/10.5367/te.2015.0483

Rousan, R.A., Ibraheim, H., Bader, M., \& Khasawneh, N. (2020). Sustainable Tourism Development in Jordan.Measuring Customer Satisfaction of American Tourists Visiting Petra and Mount Nebo in Jordan. Journal of Environmental Management \& Tourism, 11(4 (44)), 1001-1012. https://doi.org/10.14505/jemt.v11.4(44).26

Schaufeli, W.B. (2018). Work engagement in Europe. Organ.Dyn, 47, 99-106. https:doi.org/10.13140/RG.2.2.10491.31520

Sharma, A. (2013). Destination marketing: Hamper of opportunities for tourism industry. International Journal of Management Sciences and Business Research, 2(5), 20-30.

Shunnaq, M., Schwab, W.A., \& Reid, M.F. (2008). Community development using a sustainable tourism strategy: a case study of the Jordan River Valley tourist way. International journal of tourism research, 10(1), 1-14. https:doi.org/10.1002/jtr.620

Simpson, P.M., \& Siguaw, J.A. (2008). Destination word of mouth: The role of traveler type, residents, and identity salience. Journal of Travel Research, 47(2), 167-182. https:doi.org/10.1177/0047287508321198

Singh, S., Charu, A., \& Tyagi, M. (2016). Role of culture and traditions in promotion of tourism. Journal of Latest Technology in Engineering Management and Applied Science. 5(2), 2278-2540

Thrane, C., \& Farstad, E. (2012). Nationality as a segmentation criterion in tourism research: The case of international tourists' expenditures while on trips in Norway. Tourism Economics, 18(1), 203-217. https://doi.org/10.5367.te.2012.0110

Trillo, C., Aburamadan, R., Udeaja, C., Moustaka, A., Baffour, K.G., \& Makore, B.C.N. (2020). Enhancing heritage and traditional architecture conservation through digital technologies.Developing a digital conservation handbook for As-Salt, Jordan. In International symposium: New Metropolitan Perspectives, 211-219, Springer, Cham. https:doi.org/10.1007/978-3-030-52869-0

Trusov, M., Bucklin, R.E., \& Pauwels, K. (2009). Effects of word-of-mouth versus traditional marketing: findings from an internet social networking site. Journal of marketing, 73(5), 90-102. https:doi.org/10.1509/jmkg.73.5.90

Wang, Y., Yu, Q., \& Fesenmaier, D.R. (2002). Defining the virtual tourist community: implications for tourism marketing. Tourism management, 23(4), 407417. https:doi.org/10.1016/S0261-5177(01)00093-0

Wolfe, Sr.M.J., \& Crotts, J.C. (2011). Marketing mix modeling for the tourism industry: A best practices approach. International Journal of Tourism Sciences, 11(1), 1-15. https:doi.org/10.1080/15980634.2011.11434633

Zalloom, B. (2020). Enhancing Tourism by Reconnecting the Fragmented Landscape of WadiAraba in Jordan. Journal of Urban Planning and Development, 146(3), 05020010. https:doi.org/10.1061/(ASCE)UP.1943-5444.0000592

Zamil, A. (2011). The Role of Jordanian Local Community in Marketing Tourism. Journal of Business Studies Quarterly, 2(3), 42, ISSN 2152-1034

*** MOTA (2018). Tourism statistics in Jordan Retrieved from http://www.mota.gov.jo/Contents/Statistics_2018_2nd.aspx

*** UNWTO (2002). Tourism highlights Retrieved from: https://www.e-unwto.org/doi/book/10.18111/9789284406876

*** UN. (2019). Jordan Retrieved from http://jo.one.un.org/en/about-jordan/.Urquhart, C. (2012). Grounded theory for qualitative research: A practical guide. Sage. https:doi.org/10.4135/9781526402196 